\title{
Energy Sustainability through Renewable Sources in Libraries - A Study
}

\author{
T. M. Kalpana ${ }^{1 *}$ and S. Gopalakrishnan ${ }^{2}$ \\ 1'Indian Statistical Insitutute, Chennai Centre, Taramani, Chennai - 600113, Tamil Nadu, India; kalpana.ttcpl@gmail.com \\ 2National Institute of Fashion Technology, Taramani, Chennai - 600113, Tamil Nadu, India; gopusg@yahoo.com
}

\begin{abstract}
Libraries are store houses of knowledge functioning as service sector and playing major role in education all over the world. Libraries are not just enough to be user friendly but also be ecofriendly. Libraries should collect more resources but really the more the library grow it accumulates dust, pest and pollution. A poor maintained library can cause chronic disease like throat ulcer, bronchitis, and dust allergy, emit greenhouse gases. This pollution and emission can be reduced by strategic planning in utilizing energy efficiently, implementation of technological advances in library environment, making library more informative and giving library a new phase on sustainability. This paper describes on energy generation and utilization from green, fossil free, self-generated $0 \%$ emission solar power panels and wind energy structures. From a pilot scale study, nearing $100 \%$ of respondents have given their opinion that libraries have shrinking budgets and self-sustainability has become need of the hour. Self-sustainability can be attained from implementation of all possible strategies in library operations especially from energy consumption. Implementation of solar energy according to the quantity required or consumed by the library should be estimated and physical structures should be installed. These structures produce electricity from heat energy from sun, converted and supplied through specially designed batteries. Self-sufficient, energy efficient solar powered libraries around the world are taken as preamble, advantages, further implementation techniques are discussed in this paper helps to take library and environment a step head in energy sustainability.
\end{abstract}

Keywords: Energy Sustainability, Libraries, Renewable Energy, Self-sustainability, Solar Energy

\section{Introduction}

Libraries' income and funds statement are either decreasing or consistent but, not increasing relatively to the increasing cost of procurement and maintenance. The need of the situation has forced librarians to change roles and the environment in libraries, in functions, service models, infrastructure facilities, expenditure levels etc. Economic crisis prevailing in libraries forces librarians to introduce technologies that are successfully implemented in other fields that can be efficiently introduced in library with special reference to energy efficiency. Energy generated from solar power panels can cut short the expenditure curve giving room for good collection, returns on investment and green energy for all the years to come. This ultimately makes library not only user friendly but also eco-friendly.
Libraries that have good collection attract not only users but also attract dust and pollution. A poor maintained library can cause chronic disease like throat ulcer, bronchitis, and dust allergy, emit greenhouse gases and energy utilization from green fossil free self-generated, $0 \%$ emission solar power panels. Self-sufficient, energy efficient strategies, implemented in libraries around the world, taken as preamble further implementation techniques are discussed helps to take library and environment a step head in development.

\section{Materials and Methods}

Libraries that use solar power to meet the needs are studied from the web resources and analyzed for adaptability, advantages, disadvantages and estimation was done for

\section{${ }^{*}$ Author for correspondence}


implementation at small library with minimum infrastructure facilities.

\section{Results and Discussion}

\subsection{Need for Libraries to become Eco-friendly}

Global warming plays a major role in climate change and production in all fields across world. Psychological and physical evolution to the economic revolution, chemical emissions, health hazards, occupational environment, stress levels etc has made every human being to think back on being ecofriendly. Libraries being a knowledge store houses, also emits greenhouse gases considerably directly and indirectly and at this point professionals should think of going green in libraries.

\subsection{Ways of Direct Emissions to Greenhouse Gases}

1. Spraying of chemical pesticide and insecticide emits harmful chemical particles in air.

2. Generating heat from lights that glow, round the year, in all working hours, especially between shelves in stack area and reading hall.

3. To maintain cool temperature inside and age of books air conditioners are installed. This again throws out heat generated by the machine and maintains coolness inside.

\subsection{Indirect Ways of Contribution made by Library to Global Warming}

1. Consumption of electricity for infrastructure fittings like lights, fans and peripherals like computers, printers, air conditioners, room heaters and all other electronic devices. Electricity is produced from fossil fuels like carbon deposits, diesel and petrol. Production of energy from such fossil fuels emits lots of carbon-di-oxide, Sulphur-di-oxide etc. causing depletion of ozone layer.

2. Emissions from printing inks in books and other resources.

3. Emissions from raw materials used in building materials like plastics, rubber, pasting materials etc.

Contributions to greenhouse emission gases are very silent from library but on whole it shows bulky figures. The above three main contributions to greenhouse gases can be addressed by Library managers with minimum initiation namely
1. Using of renewable source of energy

2. Absorbing chemicals emitted by planting indoor plants

\subsection{Renewable Energy}

Renewable energy can be described as energy produced from renewable sources, i.e. source that are continuously available from nature and will not get depleted. Few to mention which are predominantly used are

1. Solar power

2. Wind energy

3. Hydro power

4. Biomass energy

5. Hydrogen

6. Geo thermal and

7. Ocean energy

\subsection{Energy Sustainability from Renewable Sources that are Suitable for Library Environment is Solar Energy and Wind Power}

\subsubsection{Solar Energy}

In countries like India gifted with rich solar power as a source of renewable energy throughout the stretch and round the year if utilized properly power shut downs, heavy investment on fossil fuel research, source searching, refining etc. can be avoided. At average calculations, investments on erecting solar power panels can be recovered by savings from electricity bills, within 10-13 years but production continues. Life of installed power panels are estimated from 25 to 60 years depending on the quality and maintenance. Saving more than $10 \%$ to $20 \%$ of total budget every year in library and this saved fund can be utilized for improved collection development [1], [2].

\subsubsection{Suitability and advantages of solar power as the main source of renewable energy}

1. Available round the year

2. Needs simple infrastructures exposed to sun

3. Low annual maintenance costs

4. Decentralized production and maintenance

5. Produced during day time and can be stored for utilizing during night time

6. Can be invariably utilized for all electronic appliances 
7. Recovery of investment is possible, and when compared to life of structures it gains for around 30 to 50 years of electricity bills

8. Noise, smell free silent energy production

9. No transmission cost as it is consumed locally

10. Total power requirements can be met with calculated installation [3]

11. With net meter excess produced energy can be supplied to others and earn revenue from it

\subsubsection{Other new inventions in solar revolution}

- Mobile e library and internet café with solar power for rural areas in Africa

Top of a discarded container is covered with solar panels equipped with dish antenna for internet connection. For accessing internet computers are connected and all the power requirements are met with power generated by solar panels [4].

- Solar powered library book drop box

The library funded the project and with the intensive research by students of KU university all audio visual materials can be stored in such drop boxes which can maintain recommended temperature at all extreme climatic conditions. If the temperature is too hot it cools itself and if the temperature is too cold it warms itself and the power for maintaining the temperature is produced by the solar panels installed. Heat and cold have adverse effects on materials such as CDs and DVDs, which expand, contract and even melt, costing the library money and the community resources. Through this project, the KU students provided not only a solution for the people of Lawrence, but their work may also serve people across the country [5].

Table 1 is an indicative list and it can go on and on Due to technological advances the efficiency of the solar panels are increased and cost is decreased resulting in increased production at minimum investment [6].

\subsubsection{Domestic estimation of cost recovery analysis in a library with minimum amenities}

Table 2 shows a very minimum utility of electricity in normal environment. It can be proportionately calculated to the size and fixtures of existing library with electricity needs. In the above table air conditioner is not included as they consume more electricity. If additional panels are installed with not much additional investment electricity can be produced even to meet the requirement of air conditioner also [7].

Table 1. Showing the libraries that have already implemented solar power plants

\begin{tabular}{|c|c|c|}
\hline Sl.no & Name of the library & Link \\
\hline 1 & Schertz library & $\begin{array}{l}\text { http://www.mysanantonio.com/community/northeast/news/article/ } \\
\text { Schertz-library-going-green-with-solar-power-1334291.php }\end{array}$ \\
\hline 2 & Texas' West Irving Library & http://www.ktsm.com/news/texas-library-runs-sunshine \\
\hline 3 & Ballard Library & http://www.greenroofs.org/boston/index.php?page=ballardwin \\
\hline 4 & Taiwan & $\begin{array}{l}\text { http://www.businessgreen.com/bg/news/1806716/taiwan-starts- } \\
\text { construction-solar-powered-library }\end{array}$ \\
\hline 5 & New Haven library & $\begin{array}{l}\text { http://nhregister.com/articles/2012/03/11/news/new_haven/ } \\
\text { doc4f5d6a96f1c5a590260977.txt [13] }\end{array}$ \\
\hline 6 & $\begin{array}{l}\text { Lighthouse Point Park, Common } \\
\text { Ground High School }\end{array}$ & http://www.newhavenindependent.org/index.php/archives/entry/solar/ \\
\hline 7 & Barnard Environmental School & http://www.sunviewer.net/portals/Barnard/ \\
\hline 8 & Nueva School & http://www.asla.org/sustainablelandscapes/nuevaschool.html \\
\hline 9 & Modern WaalseKrook River Library & $\begin{array}{l}\text { http://www.architecture-view.com/2011/02/05/modern-waalse-krook- } \\
\text { library-design-for-belgium/waalsek-rook-library-exterior-design/ }\end{array}$ \\
\hline 10 & $\begin{array}{l}\text { Mobile e library and internet café in } \\
\text { Africa }\end{array}$ & $\begin{array}{l}\text { http://www.zdnetasia.com/solar-powered-internet-cafes-connecting-rural- } \\
\text { africa_p6-62301084.htm\#vp }\end{array}$ \\
\hline 11 & Seoul Green roof museum and library & $\begin{array}{l}\text { http://www.treehugger.com/sustainable-product-design/zaha-hadid- } \\
\text { does-a-green-roof-in-seoul.html }\end{array}$ \\
\hline
\end{tabular}




\subsubsection{Investment requirement on solar power} panel installation

- Approximately power required

$=2000 \mathrm{~W}$

- $1 \mathrm{~W}$ of solar panel cost

- $4000 \mathrm{~W}$ of Solar panel cost

$=$ Rs. 100

$=$ Rs. $2,00,000$

- Inverter and structure cost

$=$ Rs. $6,00,000$

- cost of solar panel power system

$=$ Rs. $8,00,000$

- After 20-30\% government subsidy

\subsubsection{Investment and returns analysis}

- Daily power consumption $=2.5$ units $\times 12$ hours $=$ 30 units/day

- Monthly power consumption $=30 \times 30=900$ units/month

- 1 unit cost $=$ Rs. 5.00 per unit at subsidized rate for educational institutions (Rs. 7.00 commercial)

- $\quad$ Monthly current bill = app 900 units * Rs.5.00 per unit is Rs. 4500.00

- Yearly current bill is Rs. $4500.00 * 12$ months is Rs. $54,000.00$

- Total investment is paid back in 12-13 years (after including fixed charges etc.) but the life of installation varies from 40-60 years

- After 12-13 years saving on electricity bill is dividend on investment at the rate of Rs. 4500.00 per month provided the subsidy and rates of charging is not changed. But recent price hikes, government policies, inflation rates and with reference to the increase in tariff will definitely shorten the span on return on investment [8].

Graph 1 clearly explains the investment on infrastructure in $1^{\text {st }}$ year of implementation and the recurring cost incurred on years to come. In solar energy the savings from electricity bills is used to recover the investment made in 8-10 years. (Figures given are approximate calculations from practical implications.)

\subsubsection{Wind Energy}

According to media sources this year especially in southern districts of Tamilnadu production of power from wind mills has avoided power shut and produced more than needed. This again shows that India is gifted with another pollution free source of energy from wind mills. Comparatively this source is seasonal. Research and development can give fruitful results on mass storage of produced electricity the power problem in India and between states will be solved.

Table 2. Showing List of electrical appliances and its power consumption

\begin{tabular}{clccc}
\hline Sl.no & $\begin{array}{c}\text { Name of the } \\
\text { appliance }\end{array}$ & $\begin{array}{c}\text { Quantity used in a } \\
\text { small library in nos }\end{array}$ & $\begin{array}{c}\text { Power consumption on } \\
\text { per unit basis }\end{array}$ & $\begin{array}{c}\text { Power consumption } \\
\text { per unit in watts }\end{array}$ \\
\hline 1 & Tube light & 4 & $40^{\star} 4$ & 160 \\
2 & Fans & 4 & $70^{\star} 4$ & 280 \\
3 & Computer & 4 & $120^{\star} 4$ & 480 \\
4 & Printer & 1 & $500^{\star} 1$ & 500 \\
5 & Total & & & 1420 \\
\hline
\end{tabular}

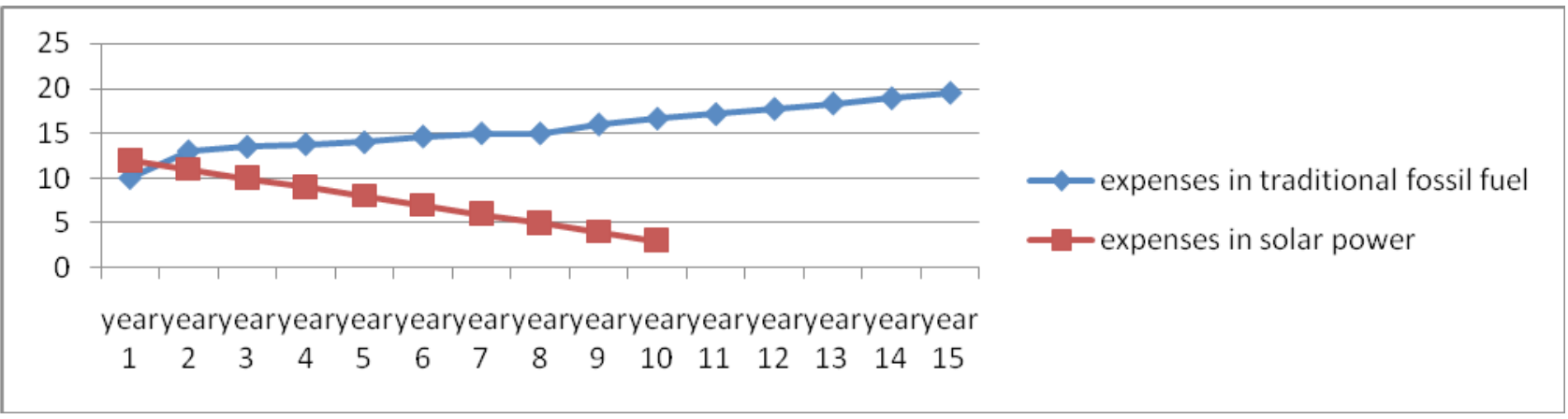

Graph 1. Showing the comparative spending and return on investment. 


\subsubsection{Features}

- Seasonal

- Requires large infrastructures

- Heavy investments

- Storage of produced electricity is not possible

- Requires large land area

- As the windmills are too height, maintenance is adhoc

\section{Indoor Plantations}

In many homes indoor plants are kept as ornamental, but it serves a healthy purpose. It removes smoke, and air pollutants and emits clean green healthy purified form of oxygen for respiration. Library is a place where many users stay and spend their valuable time. It is the duty of the housekeeping section of public library to make the environment neat, tidy and comfortable. To enhance the environment inside libraries indoor planting technique can be implemented as it has silent but many advantages with fruitful results. It helps to maintain temperature inside the building naturally, in greener way without utilizing fossil energy for artificial air conditioning [9]. Advantages of indoor plants are

1. Gives lush green natural environment to library that attracts more users

2. Absorbs noise, emitted chemicals, and other pollutants from air [10]

3. Maintains cool temperature according to the external temperature [11]

4. Soothes mental stress and comforts the users

5. Reduces carbon di oxide and increases oxygen levels that makes users feel more healthier [12]
Table 3 shows the harmful chemicals that are emitted from the building materials and printing materials which cannot be avoided. Therefore planting of these particular species of plants that are capable to absorb these pollutants will enhance the quality of air inside the library. This system gives more oxygen content in air and thus provides a smoke, smell free healthy environment in library and attracts users.

\section{Conclusion}

From the examples taken from all around the world in usage of renewable energy as source for power consumption especially in library it gives immense pressure on Indian library managers and planning engineers to think what is the reason for not utilizing the abundant free resource and depending on monopoly supplier of energy and giving more burden on government in production, subsidy, maintenance, supply etc. and wasting our paid taxes revenue. From the recent pilot scale study done among librarians about 98 percent of librarians are aware of availability of renewable resources and its importance but the main reason for not implementing renewable energy structures is lack of funds for implementation and support from the parent organization. So to motivate erection and usage of renewable source as energy supplements special initiatives like seminars, conferences or workshops should be organized. More subsidies should be provided, and if possible it should be made mandatory by law for all libraries to implement renewable sources for energy needs and special funds should be encouraged by state and central governments jointly.

Table 3. Showing the indoor plants that can remove harmful chemical pollutants

\begin{tabular}{lll}
\hline Chemicals & Pollutant sources & Pollutant removing plant varieties \\
\hline Benzene & $\begin{array}{l}\text { Inks, oils, paints, plastics, rubber, dyes, detergents, } \\
\text { gasoline, pharmaceutical, tobacco smoke, synthetic } \\
\text { fibers }\end{array}$ & $\begin{array}{l}\text { English Ivy, Dracaena marginata, Janet Craig, } \\
\text { Warneckei, Chrysanthemum, Gerbera Daisy, } \\
\text { Peace lily }\end{array}$ \\
Formaldehyde & $\begin{array}{l}\text { Foam insulation, plywood, pressed-wood products, } \\
\text { grocery bags, waxed paper, fire retardants, adhesive } \\
\text { binders in floor coverings, cigarette smoke, natural gas }\end{array}$ & $\begin{array}{l}\text { Azalea, Philodendron, Spider plant, } \\
\text { Golden Pothos, Bamboo palm, Corn plant, } \\
\text { Chrysanthemum, Mother-in-law's tongue }\end{array}$ \\
$\begin{array}{l}\text { Trichloroethylene } \\
\text { Primarily used in the metal degreasing and dry } \\
\text { cleaning industries; also in printing inks, paints, } \\
\text { lacquers, varnishes, adhesives }\end{array}$ & $\begin{array}{l}\text { Gerbera Daisy, Chrysanthemum, Peace lily, } \\
\text { Warneckei, Dracaena marginata }\end{array}$ \\
\hline
\end{tabular}

Source: http://www.wikihow.com/Stop-Secondhand-Smoke-Coming-Into-Your-Apartment 


\section{Acknowledgement}

Authors are thankful for moral support extended by family, friends and colleagues

\section{References}

1. Shahan Z., Top Solar Power Countries. Available: http:// cleantechnica.com/2012/06/12/top-solar-power-countriesper-capita-per-gdp-per-twh-of-electricity-produced-in-total/

2. DeKunder D., Schertz library 'going green' with solar power. Available: http://www.mysanantonio.com/community/north east/news/article/Schertz-library-going-green-with-solarpower-1334291.php

3. Lee C., Texas library runs on sunshine. Available: http:// www.ktsm.com/news/texas-library-runs-sunshine

4. Solar-powered Internet cafes link rural Africa to global village. Available: http://www.businessdailyafrica.com/ Solar-powered-Internet-cafes-link-rural-Africa/-/539444/ 1195700/-/8iugjb/-/index.html

5. Cahir I., KU engineering students design solar powered drop box for audio visual materials. Available: http://www.news. ku.edu/2009/may/12/dropbox.shtml

6. Chan, Y., Taiwan starts construction on solar-powered library. Available: http://www.businessgreen.com/bg/news/ 1806716/taiwan-starts-construction-solar-powered-library
7. Kalpana T.M. and Gopalakrishnan S., Collection Development with Ecofriendly technologies, Internaltional Conference on Collection Development in Digital Environment, Chennai: University of Madras, 2012, p. 421-424.

8. Tamilnadu Electricity Regulatory Commission, Determination of Generation and Distribution, Chennai, Tamilnadu, South India : Government of Tamilnadu, 2013.

9. Alter L., Zaha Hadid Does a Green Roof in Seoul. Available: http://www.treehugger.com/sustainable-product-design/ zaha-hadid-does-a-green-roof-in-seoul.html

10. Xeno., Fighting a Sore Throat with Indoor Plants and a Cigarette Smoke Remover. Available: http://xenophilius. wordpress.com/2009/10/29/indoor-plants-can-reduceformaldehyde-levels/

11. PlantsthatHelp ReduceRoom Temperatures, Available:http:// greensomethings.typepad.com/green_somethings/2009/09/ remove-pollution-plants.html

12. How to care for indoor plants, Available: http://homeofkhalifah.blogspot.in/2012/04/how-to-care-for-indoor-plants.html

13. Sanders A., Solar panels pumping out energy atop New Haven library. Available: http://www.nhregister.com/ articles/2012/03/11/news/new_haven/doc4f5d6a96f1 c5a590260977.txt 